\title{
Historical perspectives of The American Association for Thoracic Surgery: Richard Hardaway Meade, Jr (1897-1993)
}

\author{
Abe DeAnda, Jr, MD, and Leora B. Balsam, MD
}

Richard Hardaway Meade, Jr, the 35th president of The American Association for Thoracic Surgery (AATS), was born on May 10, 1897, in Richmond, Virginia (Figure 1). The son of Richard H. Meade and Eleanor (Nellie) Prior Atkins, Richard Hardaway Mead, Jr, was born into a prominent Southern family and was the older brother to Nellie and Thomas Stanley. The Meade family had originally emigrated from Ireland in 1685 and was conspicuous in early American history with 1 relative serving as an aide to General Lincoln during the Revolutionary War. Growing up in Richmond, he attended the Richmond Academy and entered the Virginia Military Institute. His slight stature (at the time, he stood only $4^{\prime} 10^{\prime \prime}$ ) coupled with his ability in math engendered a level of protection from the upperclassmen whom he tutored. Unfortunately, because he was not demonstrating any evidence of a growth spurt, he was withdrawn from the Virginia Military Institute and enrolled in Richmond College (Figure 2) before transferring to the University of Virginia, graduating with his premedical Bachelor's degree in 1917.

Active in his church and community, while attending a YMCA convention in Georgia, Richard Hardaway Meade, Jr, heard a speech that encouraged those in attendance to pursue careers in which they could most affect humanity. With this inspiration and the support of his family, he decided to study medicine and subsequently matriculated at Harvard Medical School, from which he graduated in 1921. He obtained postgraduate training at the Trudeau Sanatorium in New York on the shore of Saranac Lake, then a premier site for the study and treatment of tuberculosis. It was at Saranac that he first met his future wife. He then began his formal surgical training, interning at the Willard Parker Hospital and taking a residency at Presbyterian Hospital in New York City. He described to his son performing emergency tracheotomies on patients with influenza en route to the hospital (personal communication, F. Meade, 2015). He received an additional 6 months of training at the University of Pennsylvania in 1924. On

\footnotetext{
From the Department of Cardiothoracic Surgery, New York University-Langone Medical Center, New York, NY.

Disclosures: Authors have nothing to disclose with regard to commercial support.

Received for publication March 6, 2015; accepted for publication March 15, 2015; available ahead of print April 9, 2015.

Address for reprints: Abe DeAnda, Jr, MD, Department of Cardiothoracic Surgery,

NYU-Langone Medical Center, 530 First Ave, Suite 9V, New York, NY 10016

(E-mail: abe.deanda@nyumc.org).

J Thorac Cardiovasc Surg 2015;150:1019-22

$0022-5223 / \$ 36.00$

Copyright $(2015$ by The American Association for Thoracic Surgery

http://dx.doi.org/10.1016/j.jtcvs.2015.03.017
}

June 14, 1924, he married Mary Frazier, the daughter of Dr Charles Harrison Frazier, the Professor and Chairman of Neurosurgery at the University of Pennsylvania. He had not forgotten his original intent, and on completion of his training, he set out to fulfill his goal of having an "impact on humanity." At the time, there was a paucity of physicians in China; with the financial support of the medical mission program of the Protestant Episcopal Churches of the United States (both he and his wife were descendants of Episcopal Bishops), he traveled to the Peking Union Medical College, where he was an assistant resident, and then to St James Hospital in Anking, where he was a surgeon.

Meade's time in China provided him with a wealth of experience but also had its momentous and occasionally trying times. His namesake and first of 4 sons was born there in 1925. While Meade maintained his commitment to service to humanity, he became disillusioned with religion because of the treatment of the Chinese natives by the religious missionaries, specifically how priority treatment was given to Chinese who had become or would agree to become Christians. In addition, while he was working in China, the Chinese civil war was also proceeding, and with Chiang Kai-shek's Northern Expedition, the foreign missions became prey to the National Revolutionary Army. The navies of England, the United States, Japan, France, and Italy provided military relief and protection during the evacuation of the missions along the Yangtze River, and in 1927 Meade found himself with his family safely ensconced in a cargo boat heading back to the United States.

Returning to the United States, Meade became an Assistant Professor of Surgery at the University of Virginia. It was there that he became interested in thoracic surgery. Two more sons came along during the Virginian years: Charles Frazier and James Gardiner. He also began actively participating in the relatively fledgling AATS. In 1931, he moved on to Philadelphia, where he was an Associate Professor at the University of Pennsylvania, a staff physician at Episcopal Hospital, and a consultant at the Home of Consumptives. His fourth son, David Everard, was born in Philadelphia in 1935. This same year, he became the secretary of the AATS, a position that he would hold for 12 yearsto date the longest anyone has served in this office. In addition to his passion for the AATS, he was also called on to assist Dr Evarts Graham (AATS president 1927-28) with The Journal of Thoracic Surgery, the precursor to The Journal of Thoracic and Cardiovascular Surgery. He served as 
the Associate Editor from 1938 to 1947 and subsequently as a member of the Advisory Editorial Board.

In 1941, Meade was named the Chief of the Division of Thoracic Surgery, Department of Tuberculosis, at Graduate Hospital, which at that time was the clinical teaching facility for the University of Pennsylvania Graduate School of Medicine. Shortly afterward, World War II broke out, and he volunteered for the Army Medical Corps, being commissioned as a Major in May of 1942. He was initially assigned to Fitzsimons Army Hospital in Denver but was subsequently transferred to Kennedy General Hospital in Memphis, where he was named Chief, Chest Surgery Section. He was promoted to Lieutenant Colonel and was awarded the Legion of Merit for his service. His observations on the extent and treatment of thoracic injuries of returning veterans provided the military medical corps with a wealth of information for subsequent protocols in the treatment of soldiers with chest wounds.

After Meade left the service, he initially moved to Chicago, where he worked at Northwestern and the Hines Veterans Hospital. Having divorced in the early 1940s, he married Mary Alice Martin in November of 1946. He had first met Martin when she was in Peking. While he enjoyed his time in Chicago, his wife was from Grand Rapids, Michigan, so in 1948, he moved there, where he would spend his remaining days.

On May 7, 1956, Meade delivered his Presidential Address at the 36th Annual Meeting of the AATS. He began by noting that Article II of the Constitution of the AATS suggested that the AATS was not established to honor those who had made contributions to thoracic surgery but to encourage the work in this field. Given his interest in medical history, the thesis of his presentation was recognition that the field did not always recognize surgeons and physicians who contributed to its progress. He began by discussing the development of decortication for hemothorax and empyema, a circumstance that occurred before the development of antibiotics and transfusion. With primary credit given to Fowler (1893) and Delorme (1895), Meade noted that Carl Eggers (AATS president 1935-1936) had revisited this seldom used procedure as a result of the influenza epidemic of 1918, which frequently resulted in empyema in survivors, publishing his experience ${ }^{2}$ but subsequently never receiving credit for his role in the reemergence of this technique.

Moving next to surgery on the heart, Meade remarked that "The recently trained thoracic surgeon today, looks upon mitral commissurotomy as we older men looked upon appendectomy" and noted that the procedure was proposed in 1902 by Sir Lauder Brunton. ${ }^{3}$ Brunton was criticized for suggesting the procedure without trying the technique himself, despite the common knowledge that Brunton was a cardiologist and not a surgeon. Thus, Brunton remained fairly forgotten, whereas the more familiar names of Souttar, Bailey, Harken, and Brock received the credit.

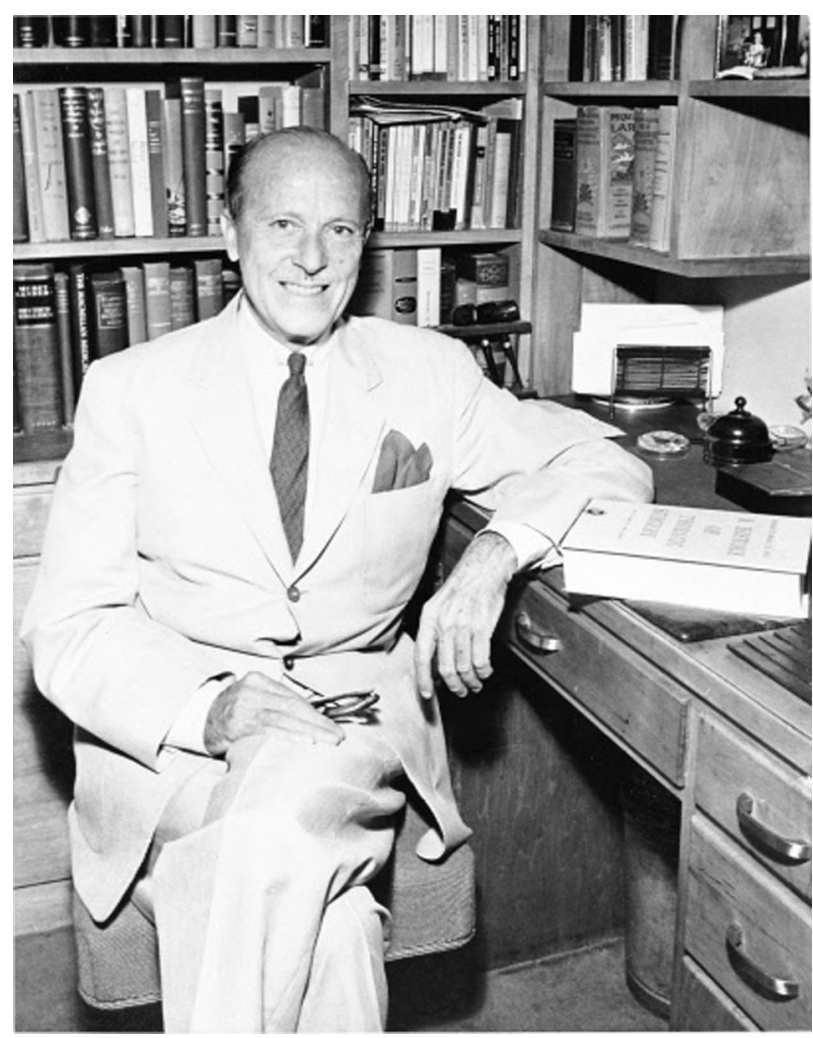

FIGURE 1. Richard Hardaway Meade, Jr.

Meade finished by tracing the history of the ligation of the patent ductus arteriosus, beginning with Munro's ${ }^{4}$ proposed correction presented at the 1907 meeting of the Philadelphia Academy of Surgery. His fascinating historical account of this procedure begged the question as to why 30 years elapsed before the operation was attempted by Strieder and then popularized by Gross. He concluded his address by stating "...I wish to add to the illustrious list known to everyone, the names of some less well known but surely deserving of attention." 5

With his long service as secretary of the AATS, Meade had the opportunity to meet and develop friendships with a number of leaders in the field, including Holman (AATS president, 1953-1954) and Gibbons. He established a friendship with Alfred Blalock (AATS president, 19501951). They corresponded frequently, and the tenor of their letters suggests both mutual respect and a level of mentorship that Blalock provided Meade. Along with I. S. Ravdin and I. A. Bigger (AATS president, 1946-1947), Blalock supported Meade's application for membership in the American Surgical Association. Meade was also planning on writing a book on the history of thoracic surgery, and with letters of introduction provided by Blalock to such luminaries as Dubost, Leriche, and d'Allaines, Meade embarked on a tour of the European centers of surgery to obtain firsthand accounts of the development of the field, an 


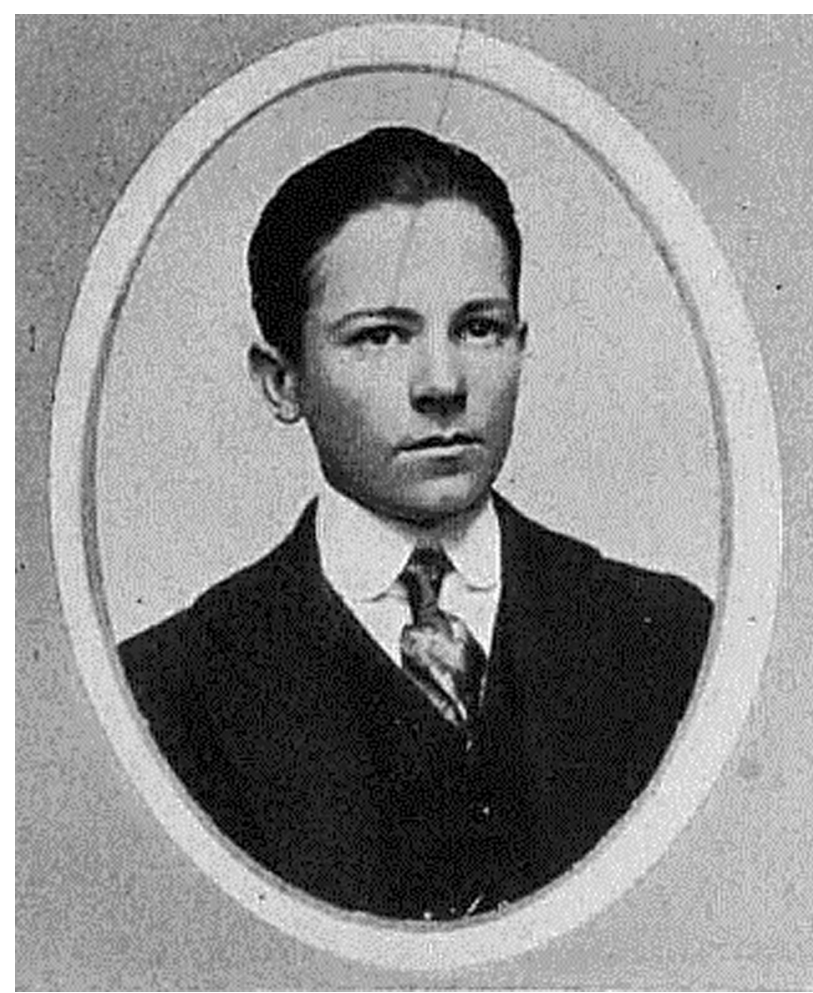

FIGURE 2. Richard Hardaway Meade, Jr, circa 1915.

extensive trip that he completed in 1955 . The result was $A$ History of Thoracic Surgery, with a foreword by Holman and first published in $1961 .{ }^{6}$
One position that Meade wanted and was not able to obtain was that of editor of The Journal of Thoracic Surgery. In 1957, Graham was stepping down as Editor, and it was Meade's impression that there was a desire that the Journal remain in St Louis with Tom Burford (AATS president, 1970-1971), Dr Graham's successor as Chief of Thoracic Surgery at Washington University, as the obvious choice to take over the editorship. Meade wrote Blalock asking for his support for his candidacy, expressing his vision for the reorganization and the role that the editor should play, concluding in his letter "...I have written frankly to you about this matter. If you feel that I am not the right person for the office I shall not feel badly about it." Instead of Burford, the job went to Holman.

The pace of Grand Rapids apparently suited him well (Figures 3 and 4). He was an avid golfer (a hobby he picked up with his younger brother while in Richmond), reader of "... voluminous and almost catholic taste...both contemporary and historical treatises," as well as poetry, and was "...known for driving his convertible in all sorts of weather" with the top down until discouraged by his dermatologist. Despite his years spent in China “...he would always scoff at the Chinese food that we brought home....we delighted in serving him the beef with broccoli, as every time he would say the same thing'Broccoli...I never had broccoli in China. I never saw broccoli in China."' (personal communications, F. Meade and S. Boucher, 2015). While in Grand Rapids, he also continued his scholarship in medical history, producing

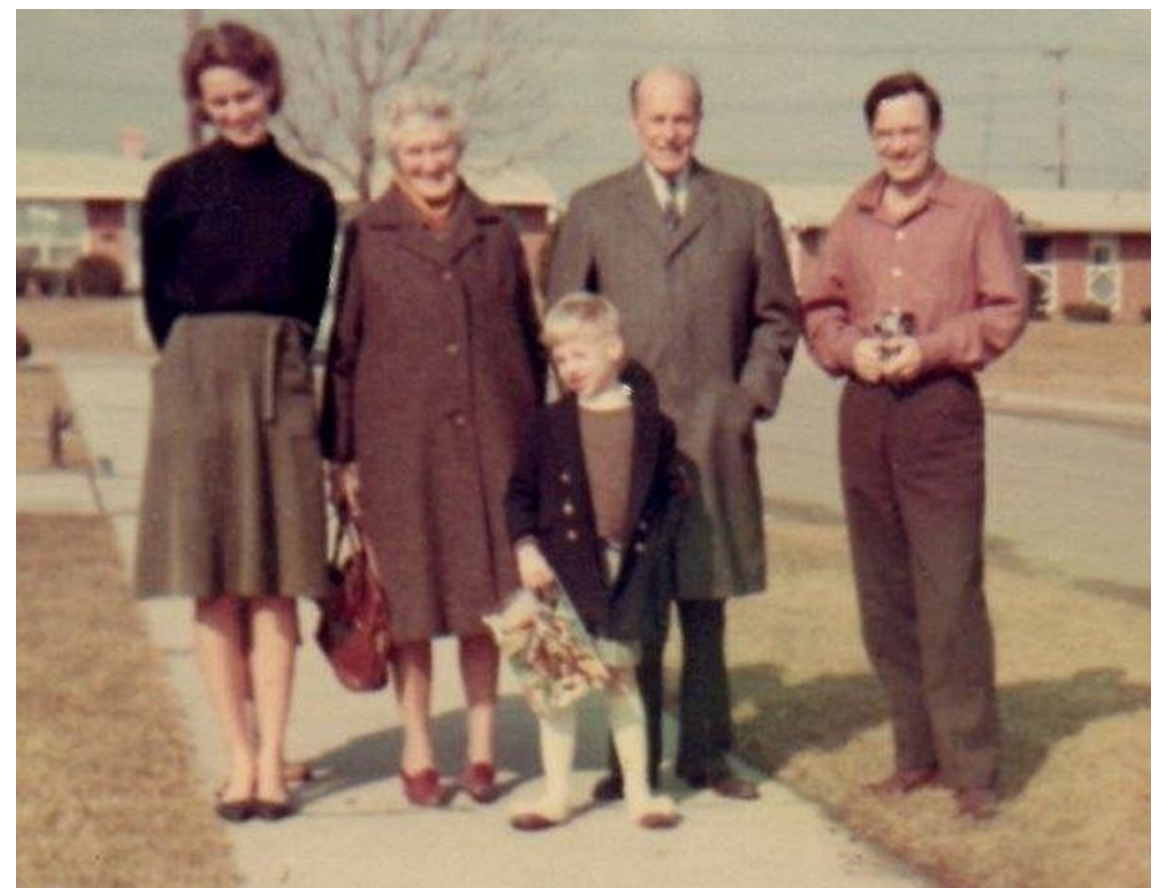

FIGURE 3. Family photograph, Ann Arbor, Michigan, 1966. Richard Hardaway Meade, Jr, with his second wife, Mary Martin, his son and daughter-inlaw, Frazier and Susan, and his grandson, Andrew. 


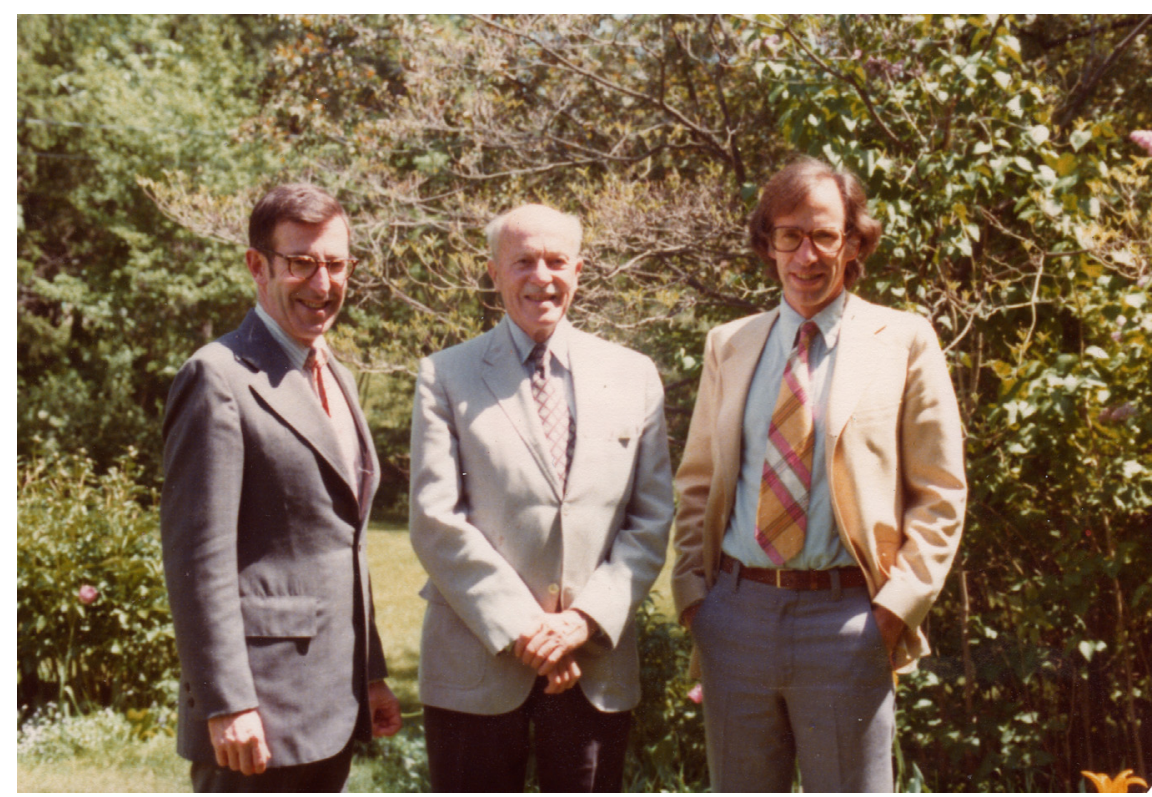

FIGURE 4. Richard Hardaway Meade, Jr (center), with his sons, Richard H. Meade III (left), and David Everard Meade (right).

the books An Introduction to the History of Surgery ${ }^{8}$ in 1968 and In the Sunshine of Life: A Biography of Dr Richard Mead 1673-1754 in 1974.

Richard Hardaway Meade, Jr, died on February 5, 1993. He should be remembered for his many contributions to the field of thoracic surgery and the AATS. He was noted as "...a sincere man, a true physician, who applies the Hippocratic principles not only in the practice of medicine but in all human relationships, ${ }^{10}$ a well-deserved tribute.

The authors thank Dr Meade's son, Frazier Meade, and granddaughter, Sarah Boucher, for providing valuable information and insight. Correspondence between Alfred Blalock and Richard Hardaway Meade, Jr, was provided from the Alfred Blalock Collection, The Alan Mason Chesney Medical Archives of The Johns Hopkins Medical Institutions.

\section{References}

1. Kay EB, Meade RH Jr. War injuries of the chest. Surg Gynecol Obstet. 1946;82: 13-24.

2. Eggers C. Radical operations for chronic empyema. Ann Surg. 1923;77:327-53.

3. Brunton L. Preliminary note on the possibility of treating mitral stenosis by surgical methods. Lancet. 1920;1:352.

4. Munro J. Ligation of the patent ductus arteriosus. Ann Surg. 1907;46:335.

5. Meade RH. Some of the forgotten men in the field of thoracic surgery. J Thorac Surg. 1956;32:139-49.

6. Meade R. A History of Thoracic Surgery. Oxford, UK: Blackwell Scientific Publications; 1961.

7. Meade RH. Personal communication to A Blalock. The Alan Mason Chesney Medical Archives of the Johns Hopkins Medical Institution. Baltimore, MD: Alfred Blalock Collection; April 22, 1957.

8. Meade RH. An Introduction to the History of General Surgery. Philadelphia, PA: W.B. Saunders Co; 1968.

9. Meade RH. In the Sunshine of Life: A Biography of Dr. Richard Mead, 16931754. Pittsburgh, PA: Dorrance \& Co; 1974.

10. Rasmussen RA. Richard H. Meade; both master and student of thoracic surgery. $J$ Mich State Med Soc. 1956;55:198-9. 